Review Article

\title{
Antarctic Palaeoclimate Variability on Millennial, Centennial and Decadal Time Scales: Indian Initiatives During 2010-2015
}

\author{
MELOTH THAMBAN*, C M LALURAJ and RAHUL MOHAN \\ ESSO - National Centre for Antarctic and Ocean Research, Headland Sada, Goa 403 004, India
}

(Received on 12 April 2016; Accepted on 12 May 2016)

\begin{abstract}
Palaeoclimatic reconstructions using diverse types of climatic archives and proxies help us in understanding the long term climatic variability and improve our knowledge for climate change perspectives. Globally, the Cenozoic was characterized by the cyclicity of glacial and interglacial fluctuations at regular intervals. Understanding the Antarctic climate variability on millennial, centennial to decadal level is crucial to our knowledge on the role and response of Antarctic ice sheets to the global climate variability. During the period 2010-15, the Indian scientists have used a variety of palaeoclimate records like marine/lake sediment cores and ice cores, mainly from the East Antarctica and its margins. The Indian studies have made significant contributions to the understanding of Antarctic climate variability and the various factors involved. Among the diverse types of studies undertaken, the ice core studies have generated large amount of knowledge basis on the Antarctic climate and its global/ regional linkages. Recent developments in the recovery and study of undisturbed sedimentary records from Antarctic lakes for the first time in the country provide an excellent opportunity to understand the last glacial to Holocene variability with better stratigraphic constraints. Compared to these, deeper sedimentary records from the Antarctic continental margin offer us an important opportunity to study of evolution and dynamics of the Antarctic cryosphere from its inception.
\end{abstract}

Keywords: Palaeoclimate; Ice Core; Sediment Core; Cenozoic; Antarctica

\section{Introduction}

Palaeoclimatic studies help us in understanding the long term climatic variability and improve our knowledge for predicting climatic changes. Climate models, supported by various observations indicate that the polar regions are highly sensitive to rising atmospheric $\mathrm{CO}_{2}$ concentrations and associated global warming. However, the high-latitude response to ongoing and future warming in a high- $\mathrm{CO}_{2}$ world remains uncertain due to the lack of understanding of the complex interactions between Antarctic cryosphere and the global climate system. Locked up in its ice sheet is a record of the history of life and environment for the last several thousands of years. It is now widely recognized that Antarctica plays a vital role in the dynamic linkages that couple the spatially and temporally complex components of the Earth's system (atmosphere, biosphere, hydrosphere, cryosphere, lithosphere and cosmogenic input). Due to the limited and the short period of observational and instrumental data on Antarctic climatic variables, our knowledge of the functioning of Antarctica within the global system and the spatial and temporal complexity of Antarctic climate is still poor. Fundamental questions remain in this approach are: How typical of Antarctic climatic history is the recent variability? Has Antarctica experienced a typical spatial climate pattern over the last several centuries to thousands of years, as suggested for other regions of the globe? Understanding the Antarctic climate variability on an array of timescales (millennial, centennial to decadal timescales) is crucial to our knowledge on the role and response of Antarctic ice sheets to the global climate variability.

\section{Results and Discussion}

Major areas of paleoclimate research in Antarctica by Indian scientists are ice core, lake sediment core 
and IODP (Integrated Ocean Drilling Program) cores from three major areas of the East Antarctica (Fig. 1). While the Indian ice core drilling have been mainly restricted to the central Dronning Maud Land (DML), the lake sediment cores come from both DML and the Princess Elisabeth Land (PEL), whereas the IODP cores discussed here are retrieved from the Wlikes Land (Fig. 1). Unlike many other palaeoclimate records, the ice cores provide one of the most direct and accurate method to study the Antarctic climate change that allows us to go back in time and to generate continuous and highly resolved reconstructions of past climate. However, due to the limited time period that the ice cores represent in the coastal areas of Antarctica, it is imperative to have indirect climate archives like lake sediment and marginal sedimentary records. The ongoing Indian palaeoclimate research in Antarctica can be described under three categories:

1. Recent climate change in Antarctica - ice core based palaeoclimatic reconstructions

2. Late Quaternary Antarctic climatic reconstruction using lake sedimentary records

3. Cenozoic climatic variability from marginal sedimentary records of East Antarctica

In the following a brief overview of the various studies conducted by Indian scientists on the above areas are described.

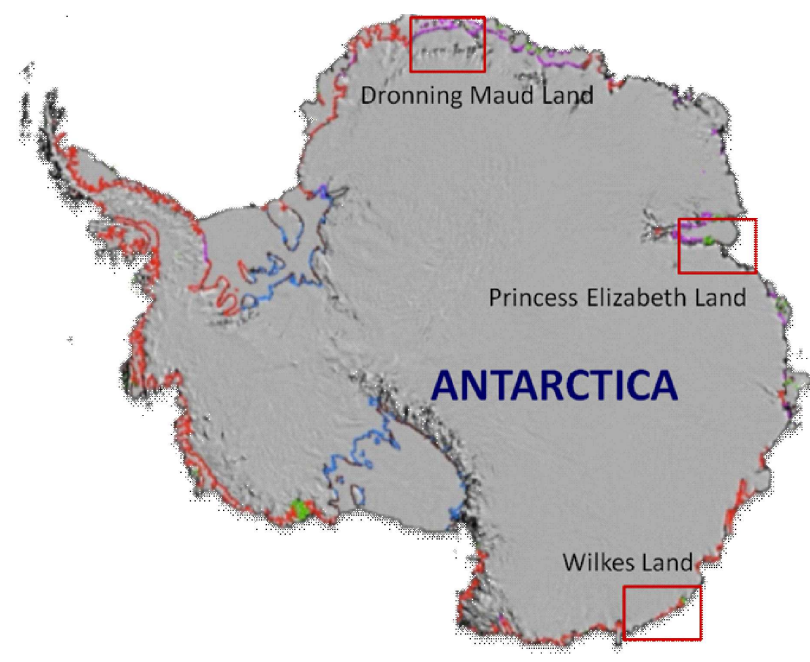

Fig. 1: Antarctic map showing the study areas discussed in the text, from where ice cores, lake sediment cores and IODP cores have been studied

\section{Recent Climate Change in Antarctica - Ice Core Based Palaeoclimatic Perspectives}

One of the major areas of Antarctic palaeoclimate research by Indian scientists during this period are the proxy based climate studies using shallow to medium depth ice cores from coastal Dronning Maud Land (DML) in East Antarctica (Naik et al., 2010a; Naik et al., 2010b; Thamban et al., 2011a; Thamban et al., 2011b; Thamban et al., 2013; Antony et al., 2012; Laluraj et al., 2011; Laluraj et al., 2014; PAGES 2k Consortium, 2013; Rahaman et al., 2016). The high-resolution (seasonal to annual) ice core studies conducted at NCAOR revealed the utility of ice records to reconstruct the natural environmental processes like the global volcanic eruptions as well as the polar and extra-tropical climatic teleconnections during the past hundreds of years.

Ice core proxy based reconstruction revealed significant changes in Southern Hemispheric climate during the past several hundreds of years (Naik et al., 2010a; Naik et al., 2010b; Thamban et al., 2011a; Thamban et al., 2011b; Thamban et al., 2013). The study revealed utility of shallow ice cores in reconstructing the past changes in major climatic modes like the El Niño Southern Oscillation (ENSO) and Southern Annular mode (SAM) (Naik et al., 2010a). Detailed analysis of the $\delta^{18} \mathrm{O}$ records of IND25/B5 covering a period of past one century (19052005) revealed a significant warming of $1{ }^{\circ} \mathrm{C}$ during 1905-2005 (Fig. 2) (Naik et al., 2010 b; Thamban et al., 2013). The oxygen isotope $\left(\delta^{18} \mathrm{O}\right)$ records from ice core (IND-22/B4) also supported significant changes in temperature during periods of solar activity as well a warming trend of $2.7^{\circ} \mathrm{C}$ for the past 470 years, with an enhanced warming during the last several decades (Fig. 3) (Thamban et al., 2011a; Thamban et al., 2011b). Further, nitrate $\left(\mathrm{NO}_{3}{ }^{-}\right)$ records the from the IND-22/B4 ice core reveals a close resemblance to the ${ }^{10} \mathrm{Be}$ record (solar proxy) from South Pole and therefore seems to demonstrating the influence of external solar forcing on the circulation pattern over the Antarctica during last 470 years (Laluraj et al., 2011). Microbiological studies of polar ice at different depths of the above ice core also provided an important comparison, as they preserve records of microbial cells and past climate conditions (Antony et al., 2012). The bacteria identified from the different depth of the ice core might have been 


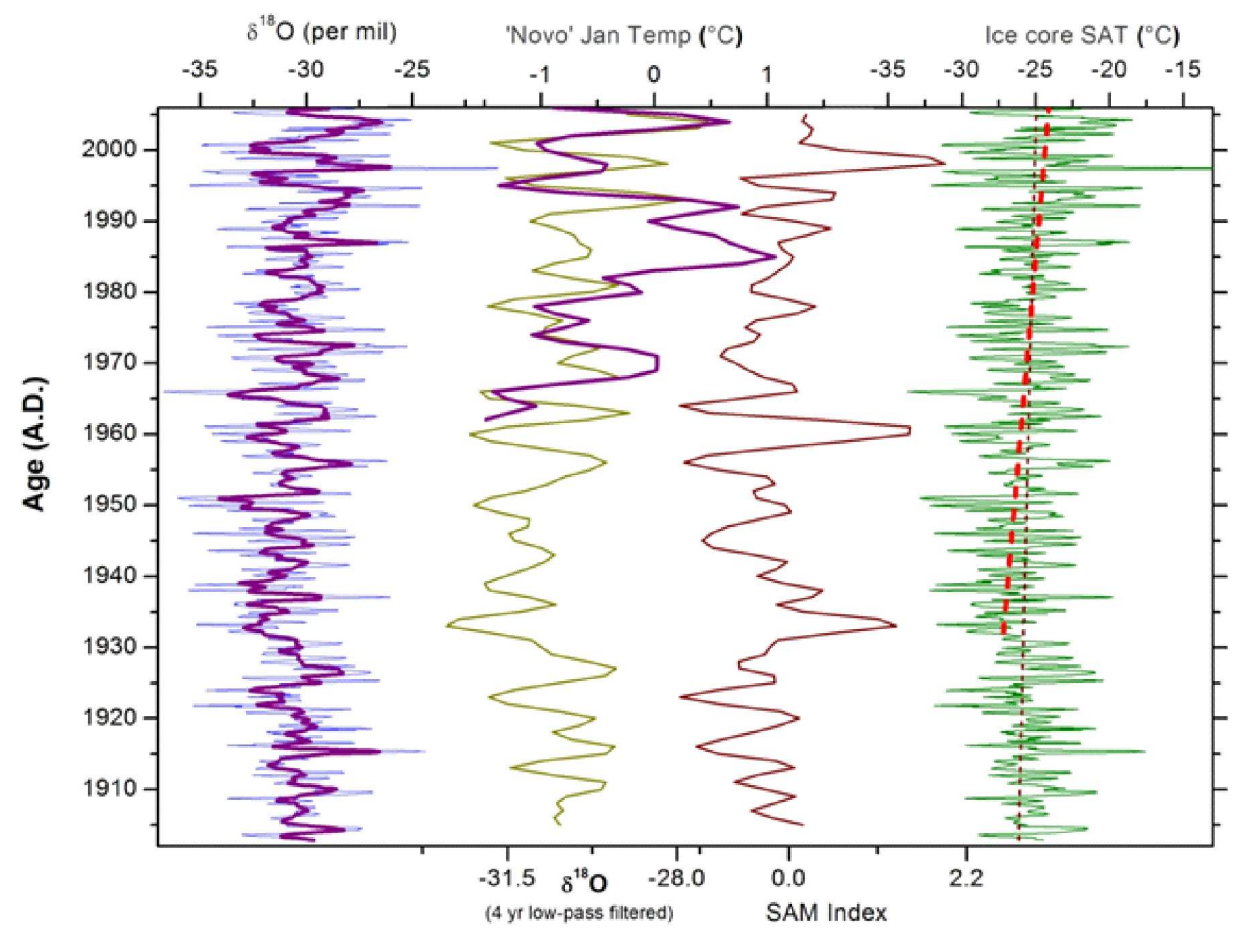

Fig. 2: Stable isotope records of climate variability at IND-25/B5 core from central Dronning Maud land, revealing the recent warming in this region (adapted from Thamban et al., 2013)

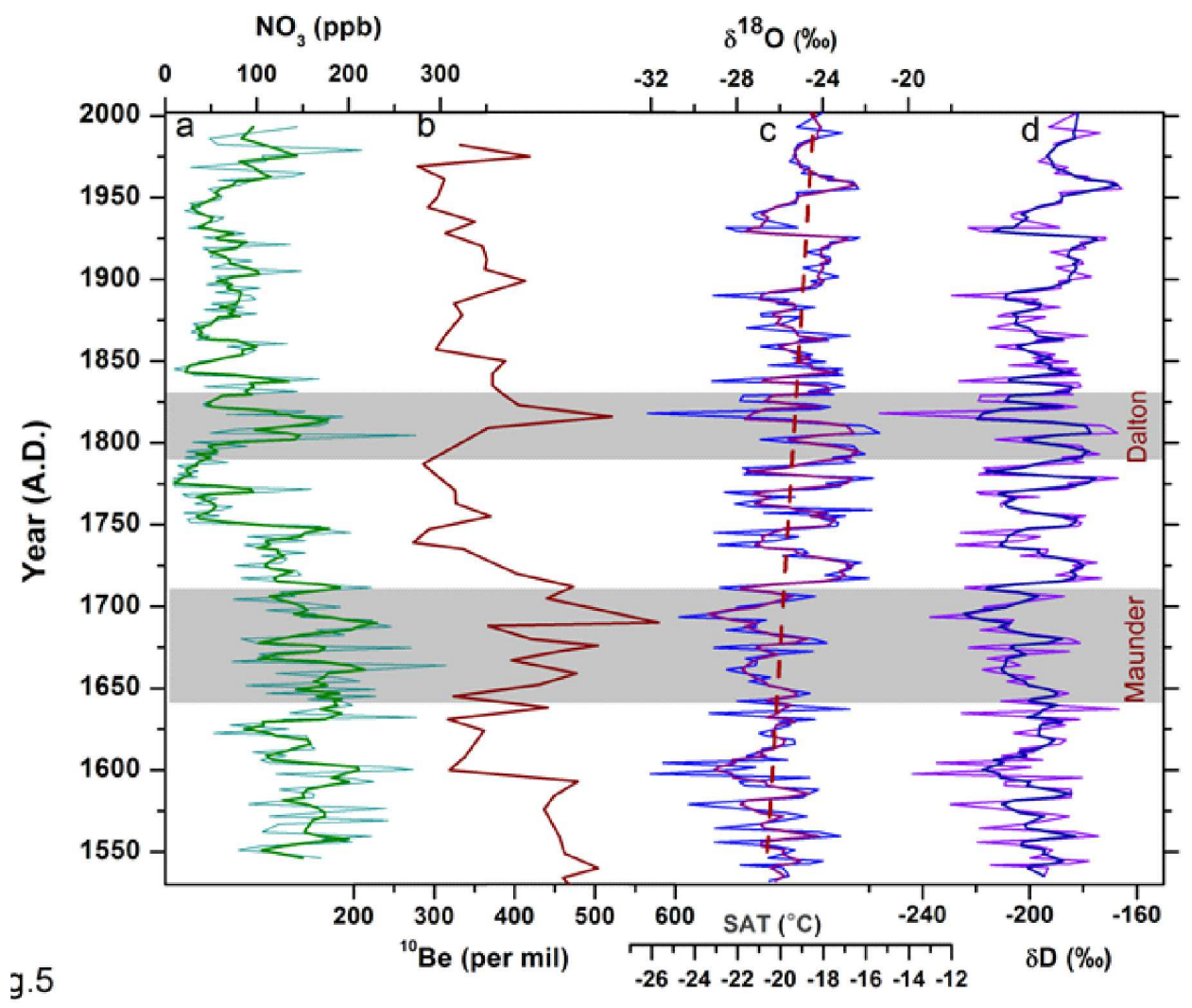

Fig. 3: Glaciochemical and stable isotope proxy records of IND-22/B4 core from DML, Antarctica and its relation with South Pole ${ }^{10}$ Be proxy data of solar variability (adapted from Thamban et al., 2011 b) 
transported and deposited into ice along with dust particles and marine aerosols.

By integrating the proxy temperature data using ice cores and various proxy records across seven continental-scale regions, a global study revealed an overall cooling trend across nearly all continents during the last two thousand years (PAGES 2k Consortium, 2013). This cooling trend was reversed by distinct warming, beginning in some regions at the end of the $19^{\text {th }}$ century. This cooling trend was reversed by distinct warming, beginning in some regions at the end of the 19th century. The dust record of IND-25/ B5 ice core showed that dust deposition in East Antarctica followed the Southern Hemispheric climate change and doubled during the $20^{\text {th }}$ century (Laluraj et al., 2014). Strong positive correlation observed between dust flux and the SAM suggests that the positive values of the SAM index are likely to be responsible for the recent increase in dust deposition over East Antarctica, through strengthening of westerly winds (Fig. 4). NCEP/NCAR reanalysis data reveals that the polar easterlies consistently strengthened since 1985 at the study region, leading to the sinking of dust materials brought by the stronger westerlies. Interestingly, the timing and amplitude of the insoluble dust flux matched remarkably well with the trace metal fluxes of $\mathrm{Ba}, \mathrm{Cr}, \mathrm{Cu}$, and $\mathrm{Zn}$, confirming that dust was the main carrier of airborne geochemical tracers to East Antarctica in the recent past (Laluraj et al., 2014). The observed doubling of dust and associated trace metal deposition in East Antarctica have wide-ranging implications for understanding the factors driving the inter-continental transportation of impurities and their environmental impact on Antarctica. These results have far-reaching implications for understanding the changes in temperature and dust levels and their impact on climate both in the recent past and future.

High resolution study of deuterium excess (dexcess), sea-salt sodium (ss- $\mathrm{Na}^{+}$) and methane sulfonic acid (MSA) in the ice core IND-25/B5 from coastal Dronning Maud Land also revealed the history of moisture transport and sea ice condition during the last century (Rahaman et al., 2015) . Sea ice extent (SIE) in the Weddell Sea was reconstructed based on Antarctic ice core records of stable oxygen $\left(\mathrm{d}^{18} \mathrm{O}\right)$, hydrogen (dD) isotopes and sea-salt- $\mathrm{Na}^{+}$. Among them, ss-Na+ flux record shows significant positive

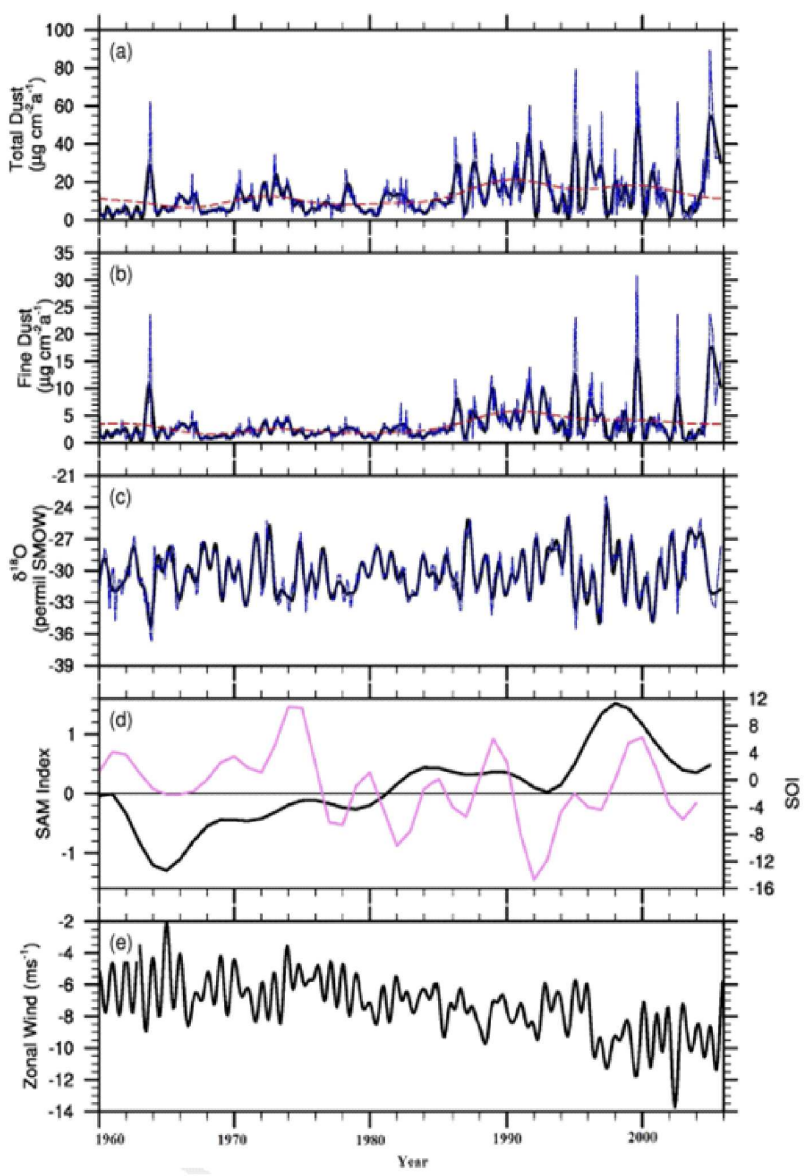

Fig. 4: High resolution records of IND-25/B5 ice core depicting: dust (a, b), oxygen isotope variations (c), Southern Annular Mode (SAM) index (d) and zonal wind (e) during 1960-2010. Strong positive correlation observed between dust flux and the SAM suggests the influence of $S A M$ on recent increase in dust deposition over East Antarctica, through strengthening of westerly winds (after Laluraj et al., 2014)

relationship with winter SIE in the Weddell Sea. Wavelet analysis of SAM index and SOI shows the highest common power in 4-8 year band during 19401960 and 1990-2000 overlapping with the period of higher SIE (Fig. 5). This shows large variability during the last century (1905-2005 AD) which impacted moisture transport from various oceanic sectors to Antarctica. Cluster of backward wind trajectories shows that air parcels were mainly originated from the Weddell Sea with additional sources from the Ross Sea and the Bellingshausen- Amundsen Sea regions. Dramatic increase in SIE was observed in the Weddell Sea sector during 1940-1980. This study suggests that 

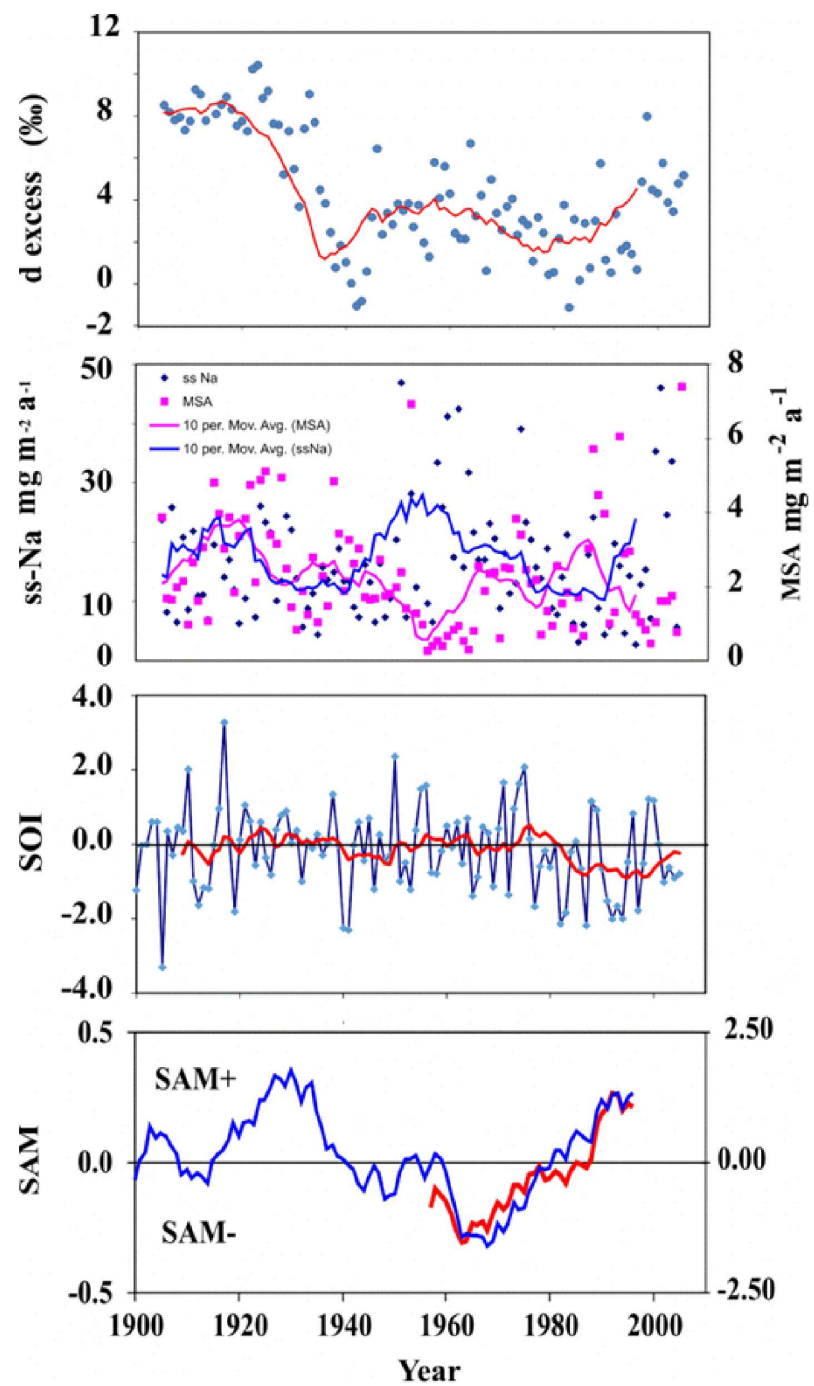

Fig. 5: High resolution proxy records of IND-25/B5 ice core showing variability in: (a). moisture variability (d excess record), (b). sea ice extent (sea salt Sodium $\left(\mathrm{ssNa}^{+}\right)$and MSA records) along with Southern Oscillation Index (SOI) and SAM index for the past 100 years (after Rahaman et al., 2016)

moisture source and sea ice variability in annualdecadal scale in Antarctica seems to be largely influenced by SAM and its teleconnection to ENSO. Further, the multifaceted scientific studies being carried out by Indian scientists in the realm of ice core paleroclimatic research will contribute significantly to the global community's ongoing efforts to better understand the past climate variability during the Holocene and its implication to the changing environment.

\section{Late Quaternary Antarctic Climatic Reconstruction Using Lake Sedimentary Records}

The continent of Antarctica is bestowed with several ice-free regions that are characterised by the presence of different types of lakes are also present in these ice-free regions which are classified into epishelf, proglacial and land-locked based on their geomorphic characteristics. Indian scientists have been actively studying the ice free regions within the logistic limitations of the Indian scientific activities around the research stations Maitri (Schirmacher Oasis, central Dronning Maud Land) and Bharati (Larsmann Hills, Princess Elisabeth Land) in the East Antarctica. The lakes in these regions contain sediments which gives a fair indication on the past climatic changes. The periglacial environment of Schirmacher Oasis and Larsemann Hills is characterized by a wide range of sedimentary and glacial processes, resulting in different combinations of erosional and depositional features (Asthana et al., 2013).

During the period under report, several studies have been made on lake sediments from Schirmacher Oasis and Larsemann Hills (Govil et al., 2011; Govil et al., 2012; Shrivastava et al., 2012; Asthana et al., 2013). Phartiyal et al. (2011) have tried to reconstruct the evolution of the Schirmacher Oasis from $13 \mathrm{ka}$ BP to the present. Results show a drastic reduction in the lake sizes by negative water balance and can possibly be attributed to the combined effect of recession of glaciers feeding them, low melt water, low precipitation and strong winds. Phartiyal (2014) described six phases 6 phases of climatic fluctuation between 13 and $3 \mathrm{ka}$ using mineral magnetic parameters; the Holocene Optima and Mid Holocene Hypsithermal are also reported. Govil et al. (2011; 2012) analyzed a sediment core from Larsemann Hills, East Antarctica to reconstruct the paleoproductivity fluctuations and factors responsible for it, based on Biogenic Silica (BSi), Sand (\%) and Total Organic Carbon (TOC). The core show prominent high productivity from $\sim 8.3$ to $\sim 6$ cal ka BP in comparison to less productivity in mid-late Holocene ( $\sim 6 \mathrm{cal} \mathrm{ka}$ $\mathrm{BP}$ to recent). Moreover, the glacio-fluvial deposition condition prevailed from $\sim 8.3$ to $\sim 5 \mathrm{cal} \mathrm{ka}$ BP. The increased productivity in the upper part of the core possibly indicates presence of algal mat due to exposure of the lake to the ice free (glacier free) conditions. Presence/absence of diatom along with 
variation of sand percentage suggests the alternate glacial-interglacial phase prevailed in this region.

Further, few studies have focussed on sediment records of the Vestfold Hills (Mazumder et al., 2013a; Mazumder et al., 2013b; Mazumder and Govil, 2013). Mazumder et al. (2013a) suggested that the constant seawater influence in the lake (which was predominated in early Holocene) got weakened after $\sim 5000$ yrs BP till date, based on diatom population and the abundance of salt crystal present in sediments. Mazumder et al. (2013b), Mazumder and Govil (2013) reported the relatively warmer climatic condition in late Holocene based on the abundance of icier condition indicator species Fragilariopsis curta along with other diatom assemblages.

Studies by the Geological Survey of India revealed that the overall characteristics and composition of the sediments in the epi-shelf lakes of the Schirmacher Oasis, are a function of source rock compositions, sediment transportation, depositional processes and weathering. The lake sediments indicates changing conditions in the transporting medium and/or the contribution of sediments from multiple provenances (Shrivastava et al., 2012). Field observations, granulometric analyses of sediment and SEM of selected quartz grains in Schirmacher Oasis and Larsemann Hills show similar results, except for the extent and strength of glacial and glaciofluvial processes. Change in energy conditions is evident from the distribution pattern of sediments in both places (Asthana et al., 2013). The sediments from Fisher Island showed a lithic arenite to arkosic composition, indicating slightly to moderately weathered source rocks. Sediments on Fisher Island show intense mechanical textures characteristic of glacial transport (Asthana et al., 2013). However, most of these records are restricted to climatic changes during the Holocene and do not provide undisturbed records of climate change due to the inherent problems associated with the sediment core and sample collection methods. In order to obtain more reliable palaeoclimate records, the "Past Climate and Oceanic Variability" project of NCAOR has embarked upon a long-term project to obtain long and undisturbed sediment cores from Larsemann Hills and Schirmacher Oasis and to undertake multi-proxy work on them to reconstruct the past climate. As part of the programme, new piston coring systems and platforms have been established for recovery of undisturbed coring over the lakes and frozen water bodies.

Based on the environmental magnetic properties of sediments deposited in Sandy Lake, glacialinterglacial climatic variation was reconstructed for the past 42.5 cal. ka B.P. (Warrier et al., 2014). This study provided environmental magnetic evidence for the Schirmacher Oasis escaping full glaciation during the past 40,000 years (Fig. 6). The magnetic mineralogy was dominated by the presence of titanomagnetite. Glacial periods were characterized by high magnetic mineral concentrations and coarse SSD titanomagnetite. The LGM has documented the highest concentration of magnetic minerals, indicating widespread glaciation in the Schirmacher Oasis. The Holocene period was characterized by alternating phases of relatively warm (12.55-9.88 cal. ka B.P. and 4.21- 2 cal. ka B.P.) and cold (9.21-4.21 cal. ka B.P. and from $\sim 2$ cal. ka B.P. onwards) events. Many of the relatively warm and cold events discerned in this study were correlatable with other lake sediment and ice-core records from the Schirmacher Oasis and other ice-free areas in East Antarctica (Fig. 6).

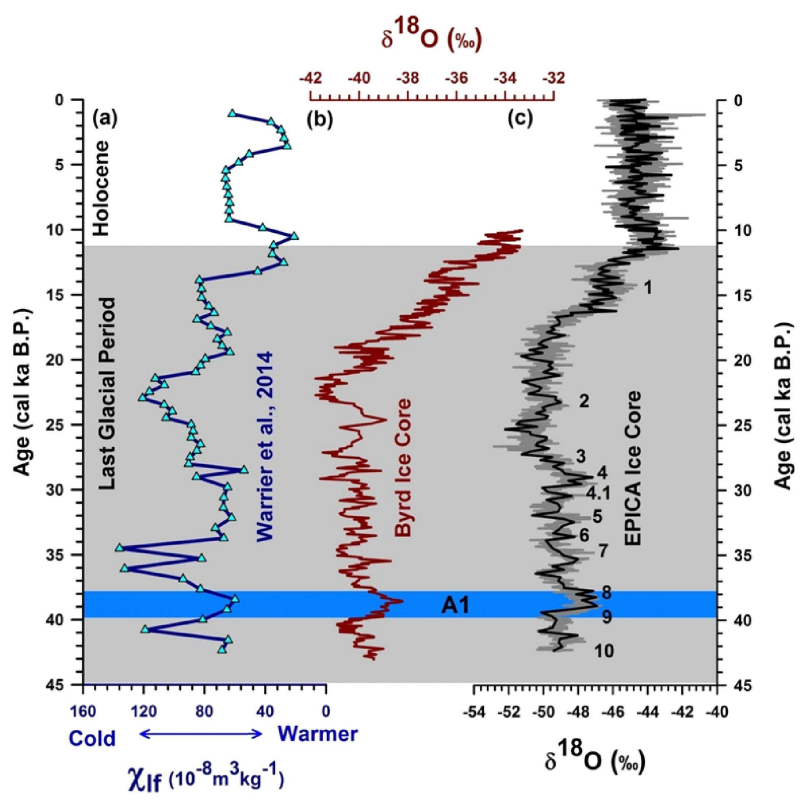

Fig. 6: Comparison of (a) magnetic susceptibility data of Sandy Lake (Schirmacher Oasis) sediments with the oxygen isotopic data of ice-cores from (b) Byrd and EDML stations in East Antarctica (after Warrier et al., 2014) 
The sediment particle size and quartz grains deposited in the sediments of Sandy Lake were used to understand their provenance and also the strength of the transporting medium during the past $42.5 \mathrm{cal}$ ka B.P. (Warrier et al., 2016). The sediments are poorly sorted and finely skewed and show different modes of grain size distribution throughout the last 43 cal ka B.P. The statistical parameters of grain size data indicate that the sediments are primarily transported by melt-water streams and glaciers. During the last glacial period, wind activity was strong as evident by the good correlation between rounded quartz data and dust flux data from EPICA ice-core data (Fig. 7). SEM studies of selected quartz grains and analyses of various surface textures indicate that glaciogenic conditions must have prevailed at the time of their transport. Semi-quantitative analyses of mineral (quartz, feldspar, mica, garnet and rock fragments \& other minerals) counts suggest a mixed population of minerals with quartz being the dominant mineral. The study reveals the different types of physical weathering, erosive signatures, and chemical precipitation most of them characteristic of glacial environment which affected these quartz grains before final deposition as lake sediments.
The organic geochemical and sedimentological data from sediments deposited in Long Lake (L-27), Schirmacher Oasis, provide a history of glacialinterglacial climatic variations during the last 48,000 cal. years B.P. (Mahesh et al., 2015). The last glacial and major part of Holocene records the lowest organic carbon indicating that the productivity was generally lower suggesting longer ice-cover period due to extreme cold conditions. The sustained Holocene warm conditions would have resulted in the lake experiencing longer ice-free conditions beginning at 6 cal ka B.P. as evident in the grain size variation. The results showed that Long Lake's response to Antarctic climate is reflected in its response to the ice-cover conditions which regulates the productivity and sedimentation in the lake system. These multiproxy records from the sediment cores will help to reconstruct high-resolution past climatic variations in Antarctica during the past.

\section{Cenozoic Climatic Variability from Marginal Sedimentary Records of East Antarctica}

In order to study of evolution and dynamics of the Antarctic cryosphere from its inception during the

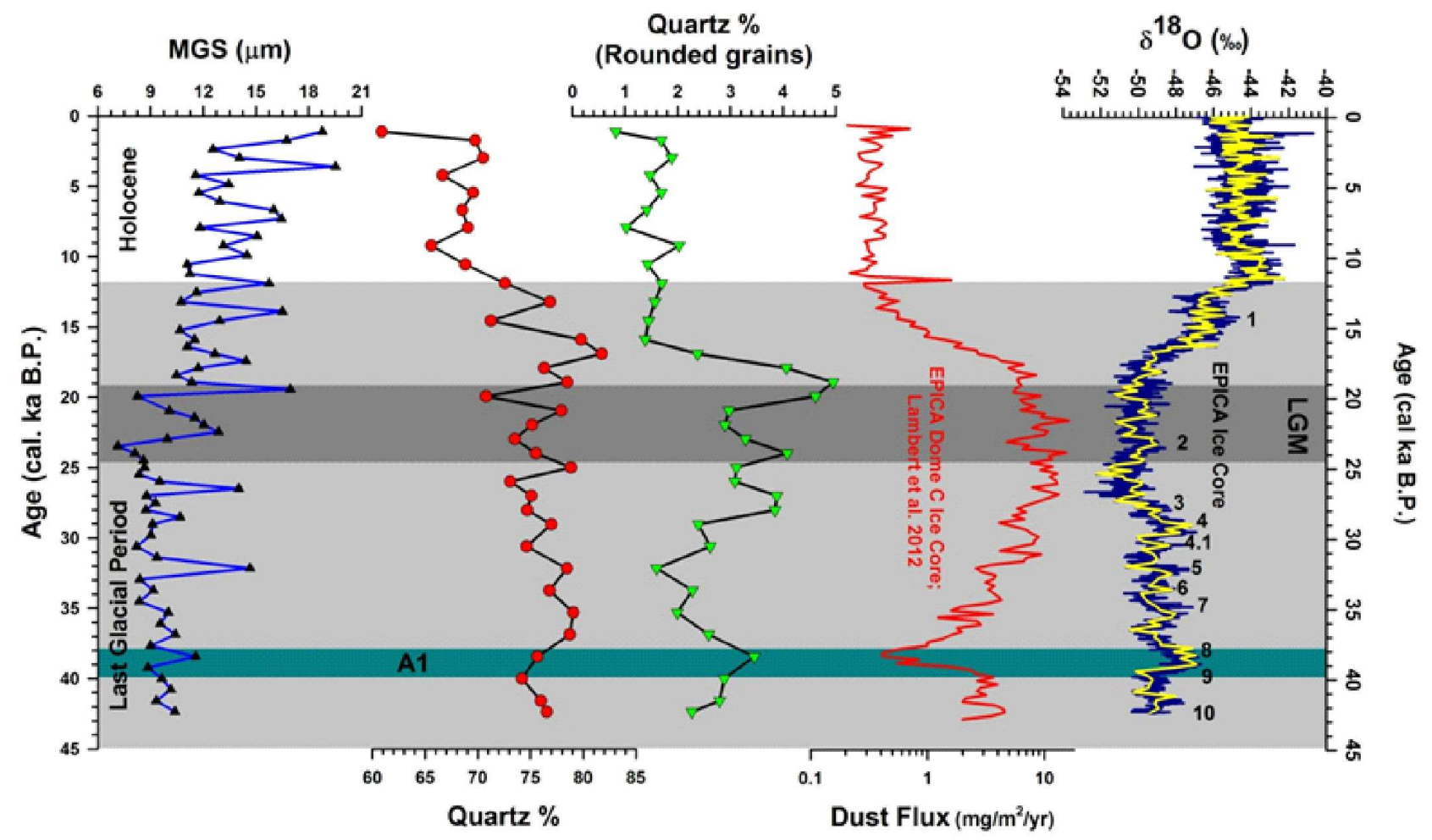

Fig. 7: Comparison of mean grain size, \% quartz, and \% rounded quartz grains of Sandy Lake core from Schirmacher Oasis (DML) with dust flux and oxygen isotopic data from EPICA ice-core data (after Warrier et al., 2016) 
Eocene-Oligocene transition ( $34 \mathrm{Ma})$ through the significant subsequent periods of likely coupled climate and atmospheric $\mathrm{CO}_{2}$ changes, Indian scientists have joined the Integrated Ocean Drilling Program (IODP) that drilled through the Antarctic Wilkes Land margin (Indian Ocean sector). The major aim was to provide a long-term record of the sedimentary archives along an inshore to offshore transect of Cenozoic Antarctic glaciation and its intimate relationships with global climatic and oceanographic change. Since paleoceanographic reconstructions from Wilkes Land margin drill cores critically depend on a robust stratigraphic framework, efforts have made for a robust chronological framework. A stratigraphic framework was developed that allows the placement of future proxy-based paleo-records into a context of global climate and ocean circulation models during a critical period of time. The record from the Wilkes Land Margin will contribute significantly to our understanding of Antarctic climate and ice sheet evolution and their feedbacks to the global climate system (Tauxe et al., 2012).

Provenance study of Pleistocene sediments from
Site U1359 of the Wilkes Land IODP Leg 318 revealed evidences for multiple sourcing from the East Antarctic Craton and Ross Orogen (Pant et al., 2013). The nature of rock fragments in Pleistocene sediments from Wilkes margin of East Antarctica and the composition of minerals is suggestive of a polymetamorphosed provenance, with peak metamorphism at least in the amphibolite-granulite transition. A subordinate low to medium grade metamorphic component is also reflected. The composition of basalt fragments suggest sediment sourcing from the Transantarctic Mountains. This implies a change of ocean currents, which is possible in the case of warmer climate and recession of the East Antarctic Ice Sheet. Increased kaolinite content in the clay mineral fraction supports this inference. Chemical geochronology of euhedral accessory minerals, indicating Ordovician-Silurian provenance ages, corroborates sediment sourcing from the Ross Orogen (Pant et al., 2013).

A global "colder" late Miocene (prior to 5.33 million years) and a 'warmer' Pliocene is commonly inferred mainly from the benthic foraminiferal records

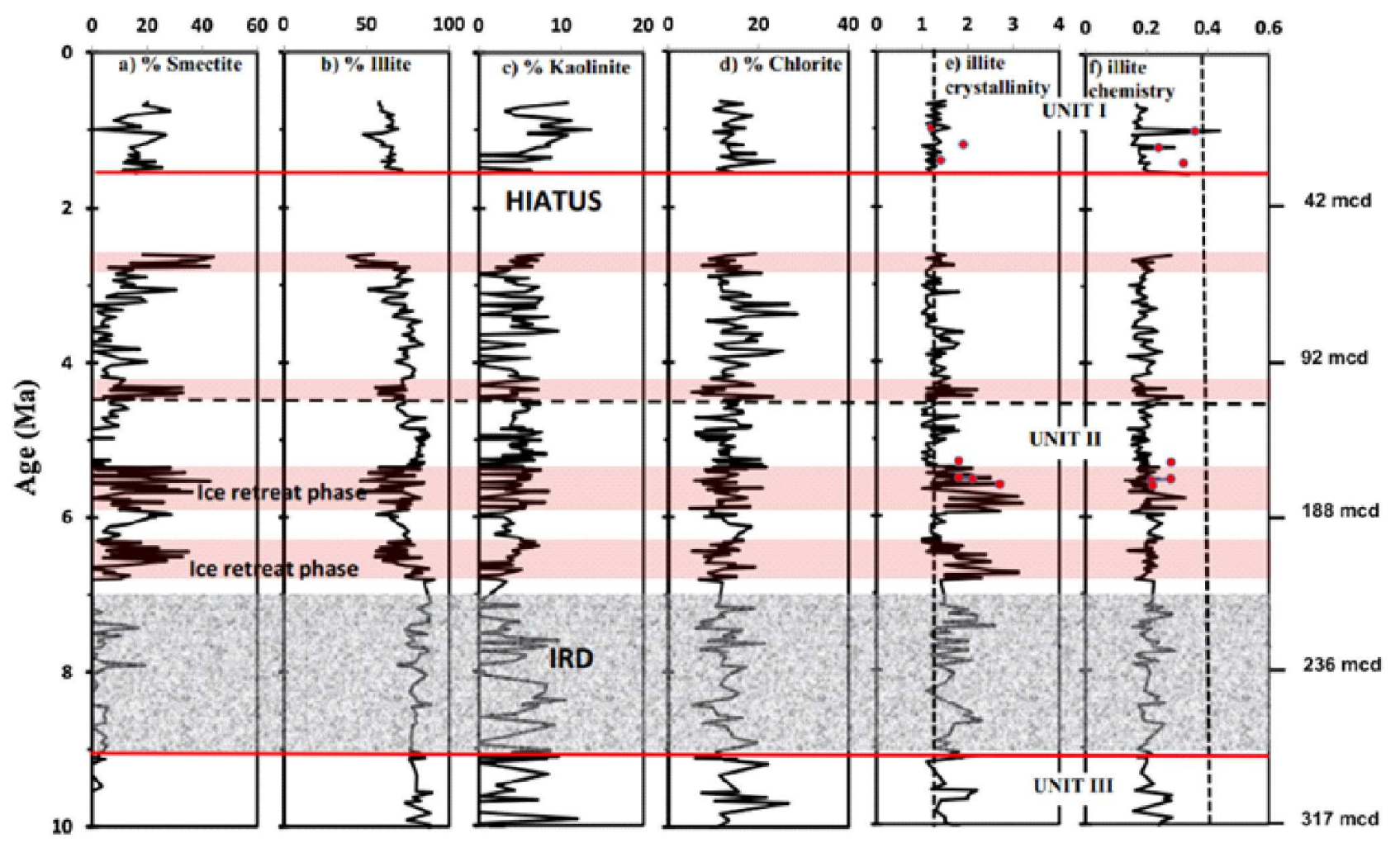

Fig. 8: Temporal variations in clay mineral records of Core U1359 collected from the continental rise off Wilkes Land at Wilkes Land, East Antarctica (after Verma et al., 2014) 
mainly from the low-latitude proxy data, but ice-sheet proximal records are limited. The clay mineralogy records of Core U1359 (IODP Hole 318) collected from the continental rise off Wilkes Land (East Antarctica) indicate that the beginning of "warming event' occurred in late Miocene rather than early Pliocene in the eastern sector of Wilkes Land (Verma et al., 2014). In their study the ice retreat condition deciphered during 6.8-6.2 Ma shows that in the eastern sector of Wilkes Land margin 'warming' had started in latest Miocene, much earlier than the other part of East Antarctica and was preceded by a concentration of IRD during 9-7 Ma period indicating a prolonged cooling period (Fig. 8). During times of ice retreat smectite rich sediment derived from Ross Orogen is transported to the core site through surface or bottom water currents (Verma et al., 2014).

\section{Conclusions}

During the period 2010-15, the Indian scientists have used a variety of palaeoclimate records like marine/ lake sediment cores and ice cores, mainly from the East Antarctica and its margins. The Indian studies

\section{References}

Antony R, Krishnan K P, Laluraj C M, Thamban M, Dhakephalkar P K, Anupama S and Shivaji S (2012) Diversity and physiology of culturable bacteria associated with a coastal Antarctic ice core Microbiological Res 167 372-380

Asthana R, Beg M J, Swain A K, Dharwadkar A, Roy S K and Srivastava H B (2013) Sedimentary processes in two different polar periglacial environments: Examples from Schirmacher Oasis and Larsemann Hills, East Antarctica Geological Society of London Special Publications 381 411-427

Govil P, Asthana R, Mazumder A and Ravindra R (2012) Grain size distribution and its influence on biological productivity during Holocene in a fresh water lake in Larsemann Hills, Antarctica National Academy of Science Letters 35(2) 115119

Govil P, Mazumder A, Tiwari A K and Kumar S (2011) Holocene climate variability from lake sediment core in Larsemann Hills, Antarctica Journal of the Geological Society of India 78 30-35

Laluraj C M, Thamban M and Satheesan K (2014) Dust and have made significant contributions to the understanding of Antarctic climate variability and the various factors involved. Among the diverse types of studies undertaken, the ice core studies have generated large amount of knowledge basis on the Antarctic climate and its global/regional linkages. Recent developments in the recovery and study of undisturbed sedimentary records from Antarctic lakes for the first time in the country provide an excellent opportunity to understand the last glacial to Holocene variability with better stratigraphic constraints. Compared to these, deeper sedimentary records from the Antarctic continental margin offer us an important opportunity to study of evolution and dynamics of the Antarctic cryosphere from its inception.

\section{Acknowledgments}

We sincerely acknowledge the inputs from Drs. N.C. Pant (Delhi University), Anish Warrier (NCAOR), Prakash Shrivastava (GSI), and Pawan Govil (BSIP), while preparing this report. This is the NCAOR contribution No. 124/2016.

associated geochemical fluxes in an ice core from the coastal East Antarctica and its linkages with Southern hemisphere climate variability Atmospheric Environment 90 23-32

Laluraj C M, Thamban M, Naik S S, Redkar B L, Chaturvedi A and Ravindra R (2011) Nitrate records of a shallow ice core from East Antarctica: atmospheric processes, preservation and climatic implications The Holocene 21 $351-356$

Mahesh B S, Warrier A K, Mohan R, Tiwari M, Anila B, Aswathi C, Asthana R and Ravindra R (2015) Response of Long Lake sediments to Antarctic climate: a perspective gained from sedimentary organic geochemistry and particle size analysis Polar Science 9 359-367

Mazumder A and Govil P (2013) Signature of warmer Late Holocene around Vestfold Hills, East Antarctica Canadian Journal of Basic and Applied Sciences 133-43

Mazumder A, Govil P, Ravindra R and Khare N (2013a) Indication of colder condition within Holocene period in a freshwater lake in Vestfold Hills area, East Antarctica region Geosciences Journal 17 235-239

Mazumder A, Govil P, Sharma S, Ravindra R, Khare N and Chaturvedi S K (2013b) A testimony of detachment of an 
inland lake from marine influence during the mid-Holocene in the Vestfold Hills region, East Antarctica Limnological Review 13 209-214

Naik S S, Thamban M, Laluraj C M, Redkar B L and Chaturvedi A (2010a) A century of climate variability in the central Dronning Maud Land, East Antarctica and its relation to Southern Annular Mode and El Niño Southern Oscillation Journal of Geophysical Research (Atmospheres) 115 D16102, doi:10.1029/2009JD013268

Naik S S, Thamban M, Laluraj C M, Redkar B L and Chaturvedi A (2010b) A century of climate variability in central Dronning Maud Land, East Antarctica, and its relation to Southern Annular Mode and El Niño; Southern Oscillation Journal of Geophysical Research 115 D16102, doi:10.1029/ 2009JD013268, 2010, 1-12

PAGES 2k Consortium (2013) Continental-scale temperature variability during the last two millennia Nature Geosciences 6 339-346

Pant N C, Biswas P, Shrivastava P K, Bhattacharya S, Verma K and Pandey M (2013) Provenance of Pleistocene sediments from Site U1359 of the Wilkes Land IODP Leg 318 evidence for multiple sourcing from the East Antarctic Craton and Ross Orogen and Iodp Expedition 318 Scientific Party Geol Soc Lon Special Pub 381 277-297

Phartiyal B (2014) Holocene paleoclimatic variation in the Schirmacher Oasis, East Antarctica: a mineral magnetic approach Polar Science 8 357-369

Phartiyal B, Sharma A and Bera S K (2011) Glacial lakes and geomorphological evolution of Schirmacher Oasis, east Antarctica, during late quaternary Quaternary International 235 128-136

Rahaman W, Thamban M and Laluraj C M (2016) Twentieth Century sea ice variability in the Weddell Sea and its effect on moisture transport: Evidence from a coastal East Antarctic ice core record The Holocene 26 338-349

Shrivastava P K, Asthana R, Roy S K, Swain A K and Dharwadkar A (2012) Provenance and depositional environment of epishelf lake sediment from Schirmacher Oasis, East Antarctica, vis-a-vis scanning electron microscopy of quartz grain, size distribution and chemical parameters Polar Science 6 165-182
Tauxe L, Stickley C E, Sugisaki S, Bijl P K, Bohaty S M, Brinkhuis H, Escutia C, Flores J A, Houben A J P, Iwai M, JiménezEspejo F, McKay R, Passchier S, Pross J, Riesselman C R, Röhl U, Sangiorgi F, Welsh K, Klaus A, Fehr A, Bendle J A P, Dunbar R, Gonzàlez J, Hayden T, Katsuki K, Olney M P, Pekar S F, Shrivastava P K, van de Flierdt T , Williams T and Yamane M (2012) Chronostratigraphic framework for the IODP Expedition 318 cores from the Wilkes Land Margin: Constraints for paleoceanographic reconstruction Paleoceanography 27 PA2214, doi: 10.1029/2012PA002308

Thamban M, Laluraj C M, Naik S S and Chaturvedi A (2011b) Reconstruction of Antarctic climate change using ice core proxy records from the coastal Dronning Maud Land, East Antarctica Journal of Geological Society of India 78 19-29

Thamban M, Naik S S, Laluraj C M and Ravindra R (2011a) High resolution reconstructions of recent warming using instrumental and ice core records from coastal Antarctica Mausam 62 665-672

Thamban M, Naik S S, Laluraj C M, Chaturvedi A and Ravindra R (2012) Antarctic climate variability during the past few centuries based on ice core records from coastal Dronning Maud Land and its implications on the recent warming. In: Earth System Processes and Disaster Management (Eds: R Sinha and R Ravindra) pp 239, Society of Earth Scientists Series, Springer, 2013, XII

Verma K, Bhattacharya S, Biswas P, Shrivastava P K, Pandey M, Pant N C and IODP Expedition 318 Scientific Party (2014) Clay mineralogy of the ocean sediments from the Wilkes Land margin, east Antarctica: implications on the paleoclimate, provenance and sediment dispersal pattern, International Journal of Earth Sciences (Geol Rundsch) DOI 10.1007/s00531-014-1043-4

Warrier A K, Mahesh B S, Mohan R, Shankar R, Asthana R and Ravindra R (2014) Glacial-interglacial climatic variations at the Schirmacher Oasis, East Antarctica: the first report from environmental magnetism Palaeogeography, Palaeoclimatology, Palaeoecology 412 249-260

Warrier A K, Pednekar H, Mahesh B S, Mohan R and Gazi S (2015) Sediment grain size and surface textural observations of quartz grains in Late Quaternary lacustrine sediments from Schirmacher Oasis, East Antarctica: Paleoenvironmental significance Polar Science 10 89-100. 